\title{
What will it take to get the evidential value of lay knowledge recognised?
}

\author{
Jennie Popay ${ }^{1}$
}

Received: 9 July 2018 / Accepted: 18 July 2018 / Published online: 26 July 2018

(C) Swiss School of Public Health (SSPH+) 2018

The Grenfell Tower fire in London on 14 June 2017 killed at least 72 people and traumatized hundreds more. Most Grenfell Tower residents were living on low incomes in Kensington and Chelsea: one of Britain's wealthiest areas. The long-term costs are not to be counted in monetary terms (significant as they are) but in deaths, grief, trauma, homelessness, fractured social connections forged over many years and increased distrust in public authorities.

More than a year later the charred tower still stands as a defiant challenge to local politicians, professionals and agencies, who put costs before safety and failed repeatedly to act on evidence of risks created by inadequate maintenance and refurbishment (Cohen 2018). The charred tower also challenges the government, which in 2013 ignored recommendations from the Parliamentary Fire Safety and Rescue Group after a similar fire. As the group's secretary presciently commented: "they seem to need a disaster to change regulations, rather than evidence" (quoted in Baynes 2017). The challenge is also to academics because the fire is the latest in a history of disasters that could have been avoided if people's experiential knowledge had been accepted as evidence.

Things were simpler in the nineteenth century. An inscription on Robert Lewis-Reid's 1896 Mural "Knowledge" distinguishes between ignorance ("the curse of god") and knowledge ("the wing where-with we fly to heaven"). Today for some academics "attempts to broaden evidence to include experiential knowledge are misguided". (Scott-Findlay and Pollock 2004) But for others "the burden of proof is on the claim that not all knowledge

This editorial is part of the section "Knowledge synthesis, translation and exchange".

Jennie Popay

j.popay@lancaster.ac.uk

http://www.clahrc-nwc.nihr.ac.uk/index.php

1 Division of Health Research, Faculty of Health and Medicine, Lancaster University, Furness Building, Bailrigg,

Lancaster LA1 4YG, UK is evidence" (Williamson 1997). Grenfell Tower residents certainly had relevant knowledge. They had tried to get the local council and the managing organization responsible for maintenance to address safety concerns for more than 5 years (Booth and Wahlquist 2017). The only response was a letter in 2013 from the council's solicitor accusing them of "defamatory behaviour" and "harassment" (Roberts 2017). Residents' concerns included faulty wiring, inadequate fire escape routes, out of date fire extinguishers, the lack of a sprinkler system and poor access for emergency vehicles (Grenfell Action Group 2013; ABC news 2017). With chilling foresight, residents warned in 2016 that: "It is a truly terrifying thought but ...... only a catastrophic event will expose the ineptitude and incompetence of our landlord.... and bring an end to the dangerous living conditions and neglect of health and safety legislation that they inflict upon their tenants and leaseholders" (Grenfell Action Group 2016).

The evidential value of people experiential knowledge-Aristotle's practical wisdom-has been well documented. Since the 1980s, for instance, the American sociologist Phil Brown (1992, 1997, 2007) has studied local people's resistance to exposure to toxic waste: activities he termed "popular epidemiology". Similarly, Williams and Popay (1994) studied residents' action on water contamination in Camelford, UK, in 1988. Like all evidence, the "trustworthiness" of experiential knowledge should be assessed, albeit in appropriate ways, but it should not be ignored.

So how can academics help us avoid more tragedies like Grenfell Tower? Some 20 years ago Popay et al. (1998) argued that "lay knowledge" was different because it challenged the way "experts" characterised problems. Pickin et al. (2002) have identified numerous factors marginalising lay knowledge in policy and practice highlighting in particular its political nature, presenting as it often does an "oppositional discourse" (Fraser 1989). The status of lay knowledge would be increased if academics treated it as legitimate evidence for review and exchange 
but despite a mellowing of the creed, and increased public involvement, the evidence movement remains obsessed with a hierarchy in which quantitative research-based knowledge reigns supreme. Murphy and Fafard (2012) put the problem this creates succinctly: "Knowledge.... can be used to...exercise discursive power in ways that privilege some definitions of health and social problems and marginalize others". As Castiel (2003) argued this is "an act of domination". It is time practitioners attended to the politics of knowledge synthesis and exchange and reflected on whether theirs is a field in which there is "a systemic lack of readiness...to recognise and respect legitimate difference and otherness" (Wynne 2008).

\section{Compliance with ethical standards}

Conflict of interest statement The author has no conflicts of interest.

\section{References}

Baynes C (2017) Ministers "ignored warnings on fire safety" before Grenfell Tower inferno. Independent https://www.independent. co.uk/news/uk/grenfell-tower-fire-latest-chief-fire-office-ronnieking-government-ignore-warnings-gavin-barwell-a7795731. html. Accesssed 8th May 2018

Booth R, Wahlquist C (2017) Grenfell tower residents say management "brushed away" fire safety concerns, in The Guardian, https://www.theguardian.com/uk-news/2017/jun/14/fire-safetyconcerns-raised-by-grenfell-tower-residents-in-2012. Accessed 8th May 2018

Brown P (1992) Popular epidemiology and toxic waste contamination: lay and professional ways of knowing. J Health Soc Behav 33:267-281

Brown P (1997) Popular epidemiology revisited. Curr Sociol 45:137-156

Brown P (2007) Toxic exposures: contested illnesses and the environmental health movement. Columbia University Press, New York

Castiel JD (2003) The urge for evidence based knowledge. J Epidemiol Community Health 57:482
Cohen D (2018) Leaked Grenfell Dossier reveals how disastrous refurbishment turned tower into a tinderbox, in Evening Standard, https://www.standard.co.uk/news/london/shock-gren fell-dossier-reveals-disastrous-refurbishment-turned-tower-intoa-tinderbox-a3814866.html. Accessed 8th May 2018

Fraser N (1989) Unruly practices, power, discourse and gender in contemporary social theory. University of Minnesota Press, Minneapolis

Grenfell Action Group (2013) Another fire safety scandal. https:// grenfellactiongroup.wordpress.com/2013/02/21/another-firesafety-scandal/. Accessed 8th May 2018

Grenfell Action Group (20 November 2016). KCTMO_playing with fire!. wordpress.com. https://grenfellactiongroup.wordpress.com/ 2016/11/20/kctmo-playing-with-fire/. Accessed 8th May 2018

Murphy K, Fafard P (2012) Knowledge translation and social epidemiology: taking power, politics and values seriously. In Rethinking social epidemiology: towards a science of change. Springer

ABC News (2017) London tower fire: residents warned of fire risk at London flats gutted by blaze, http://www.abc.net.au/news/201706-14/london-highrise-grenfell-tower-was-a-fire-risk/8617632. Accessed 8th May 2018

Pickin C, PopayJ Staley K, Bruce N, Jones G, Gowman N (2002) Developing a model to enhance the capacity of statutory organisations to engage with lay communities. J Health Serv Res Pol 7:34-42

Popay J, Williams G, Thomas C, Gatrell A (1998) Theorising inequalities in health: the place of lay knowledge. Sociol Health Illness 20:619-644

Ried RL (1896) Knowledge, mural on second floor. Library of Congress, North Corridor

Roberts R (2017) Grenfell Tower blogger threatened with legal action by council after writing about safety concerns, in Independent, 16th June 2017 https://www.independent.co.uk/news/uk/homenews/grenfell-tower-fire-blogger-threatened-legal-action-ken sington-and-chelsea-council-health-safety-a7792346.html. Accessed 15th June 2018

Scott-Findlay S, Pollock C (2004) Evidence, research, knowledge: a call for conceptual clarity. Evid Based Nurs 1(2):92-97 (discussion 98-101)

Williams G, Popay J (1994) Lay knowledge and the privilege of experience. In: Gabe J, Kelleher D, Williams G (eds) Challenging medicine. Routledge, London

Williamson T (1997) Knowledge as evidence. Mind 106:717-742

Wynne B (2008) Elephants in the rooms where publics encounter "science"?: A response to Darrin Durant, "Accounting for expertise: Wynne and the autonomy of the lay public". Public Underst Sci 17:21-33 